\title{
Research on College Students' mental health education under the background of Engineering Education Accreditation--Taking Wuhan Textile University, College of textile science and Engineering as an example
}

\author{
Qiangwei Yan, Hongxin Zhang \\ Wuhan Textile University, Wuhan 430200, China \\ Yan.wuse@aliyun.com
}

Keywords: Engineering education accreditation; Textile Engineering; College Students' mental health education.

\begin{abstract}
Under the framework of engineering education accreditation system, based on the training objectives and graduation requirements of Textile Engineering, exploring the measures of mental health education for college students majoring in textile engineering: we have established the "woven heart bay"--College students mental health education secondary station, forming a tutorial system as the starting point of College Students' mental health education system, developing mental health education of college students from school and college two aspects.
\end{abstract}

\section{The Necessity of Developing College Students' Mental Health Education Under the Background of Engineering Education Accreditation}

Engineering education professional certification refers to a specialized certification of engineering professional education set up by professional accreditation institutions for higher education institutions, which is formed by specialized occupation or Industry Association, in conjunction with the professional society in the field of education experts and experts in related industries and enterprises, industry practitioners, to provide quality assurance for the relevant preparatory education engineering and technical personnel. Accreditation of engineering education is an international quality assurance system for engineering education, which is also an important basis for international mutual recognition of engineering education and international recognition of engineer qualification. The textile engineering specialty in our school began to prepare for this work in 2016, and took the textile engineering as the key declare to Professional Engineering Education Accreditation Association. In the 2015 version of certification, quality standards for industry recognized training aim are certification standards achieved by graduate students within a certain period of time after confirmation of engineering graduates, which is a guided by the training objectives and requirements of the graduation export qualification assessment. Engineering education accreditation requires professional curriculum system, teaching staff, teaching conditions with other configuration around the students ability to emphasizes the establishment of professional mechanism for continuous improvement and culture to ensure the quality of education and professional education activity.

Studying on engineering education certification system, we can find that college students' mental health education(CSMHE) is defined as an important guidance content of the college students. In fact, the CSMHE is running through the whole process of cultivating and education of college students. The whole education activities during school are based on students' physical and mental health, and that will continue to have an important impact on their after graduation.

\section{The Framework and Content of CSMHE}

In recent years, we mainly according to "knowledge, ability and character" three-in-one training concept of mental counseling for college students, the college has set up the "undergraduate tutorial system", hired textile engineering senior professor or doctor as undergraduate academic tutor, 
according to the student's personality characteristics and preferences, CQ-forum, organized by quality supervisor face to face and other activities, carry out comprehensive guidance to students and achieve "full education" and "the whole process of educating". According to the students' growth and development rule, the college was formally established "Weaving the sun and mind, achieving the beautiful dream--The heart of the bay" mental health education base in March 2012, before the new freshmen understand autobiography growth experience and mental status of students after school by screening out the key mental survey of students, combined with the new autobiography hierarchical tracking guidance, and through the activities of mental health education series enhance the quality of students' positive mental health. In May 2012, the "Weaving the sun and mind, achieving the beautiful dream--The heart of the bay" approved "student work base" key construction projects. CSMHE activities as shown in the table1:

Table 1. Main contents of CSMHE activities

\begin{tabular}{|c|c|c|c|c|c|}
\hline \multirow{2}{*}{ Channel name } & \multirow[b]{2}{*}{ Guide executor } & \multirow{2}{*}{$\begin{array}{l}\text { Guiding } \\
\text { method }\end{array}$} & \multirow{2}{*}{$\begin{array}{l}\text { Guiding } \\
\text { frequency }\end{array}$} & \multicolumn{2}{|c|}{ Beneficiary number } \\
\hline & & & & $\begin{array}{l}\text { 2014-2015 } \\
\text { school year }\end{array}$ & $\begin{array}{c}\text { 2015-2016 school } \\
\text { year }\end{array}$ \\
\hline $\begin{array}{c}\text { Survey of } \\
\text { Freshmen's mental } \\
\text { health status }\end{array}$ & $\begin{array}{l}\text { College students } \\
\text { mental center }\end{array}$ & $\begin{array}{l}\text { Event } \\
\text { initiation }\end{array}$ & $\begin{array}{l}\text { September } \\
\text { and October } \\
\text { per year }\end{array}$ & $\begin{array}{l}\text { Professional } \\
\text { freshmen }\end{array}$ & $\begin{array}{l}\text { Professional } \\
\text { freshmen }\end{array}$ \\
\hline $\begin{array}{l}\text { Mental health } \\
\text { education of } \\
\text { College Students }\end{array}$ & $\begin{array}{l}\text { Dean's Office, } \\
\text { College students } \\
\text { mental center }\end{array}$ & $\begin{array}{l}\text { Regular } \\
\text { preaching }\end{array}$ & $\begin{array}{l}16 \text { hours per } \\
\text { academic } \\
\text { year }\end{array}$ & $\begin{array}{l}\text { Professional } \\
\text { freshmen }\end{array}$ & $\begin{array}{l}\text { Professional } \\
\text { freshmen }\end{array}$ \\
\hline Group Counseling & $\begin{array}{l}\text { College psychology } \\
\text { second level station }\end{array}$ & $\begin{array}{c}\text { Event } \\
\text { initiation }\end{array}$ & Once a year & $\begin{array}{l}\text { Professional } \\
\text { freshmen }\end{array}$ & $\begin{array}{l}\text { Professional } \\
\text { freshmen }\end{array}$ \\
\hline $\begin{array}{l}\text { Lectures on mental } \\
\text { health, Class } \\
\text { mental training }\end{array}$ & $\begin{array}{l}\text { College students } \\
\text { mental center, } \\
\text { College psychology } \\
\text { second level station }\end{array}$ & $\begin{array}{l}\text { Regular } \\
\text { preaching }\end{array}$ & $\begin{array}{l}\text { 2-3 times per } \\
\text { semester }\end{array}$ & $\begin{array}{l}\text { About } 190 \\
\text { people }\end{array}$ & About 190 people \\
\hline $\begin{array}{c}\text { mental activities, } \\
\text { Drama } \\
\text { Competition }\end{array}$ & $\begin{array}{l}\text { College students } \\
\text { mental center, } \\
\text { College psychology } \\
\text { second level station }\end{array}$ & $\begin{array}{l}\text { Event } \\
\text { initiation }\end{array}$ & $\begin{array}{l}2-3 \text { times per } \\
\text { semester }\end{array}$ & $\begin{array}{l}\text { About } 200 \\
\text { people }\end{array}$ & About 200 people \\
\hline Crisis intervention & $\begin{array}{l}\text { College students } \\
\text { mental center, } \\
\text { College psychology } \\
\text { second level station }\end{array}$ & $\begin{array}{c}\text { Event } \\
\text { initiation, } \\
\text { Student } \\
\text { counseling }\end{array}$ & Once a week & $\begin{array}{l}\text { About } 10 \\
\text { people }\end{array}$ & About 10 people \\
\hline
\end{tabular}

\subsection{College Students' Mental Health Knowledge Popularization}

The general situation of freshmen's mental health forms individual mental files. Our school carries out the work of freshmen's mental census every year from September to October, to form every year's mental health survey and individual mental health records after the completion of the census. And our school began to supplement on senior students' mental health status survey in 2016, the whole students' census results tracking guidance at the same time, arranged professional teachers to conduct a one-to-one counseling for students with abnormal mental survey results.

Set up the course of CSMHE, and take it as a compulsory course. The course consists of 32 classes, set up for freshmen each year. The teachers are the professional staff of the university students' mental health center, mainly to help students establish the correct concept of mental health, popularize the knowledge of mental health education.

Professional mental teachers are arranged to accept students' counseling in College Student Activity Center 106--mental counseling room every Monday to Friday. School holds a series of mental health campaigns for the school students in May each year. Activities include the mental drama competition, mental essay contest, mental fun games, mental knowledge contest etc. to enhance the overall level of students' mental health. 


\subsection{Characteristics of Mental Health Education Carried Out by "Weaving the Sun and Mind, Achieving the Beautiful Dream--the Heart of the Bay"}

The institute mainly depends on the "Weaving the sun and mind, achieving the beautiful dream--The heart of the bay"--mental health education for the students' professional workstation to carry out the work of mental health education, and equipped with a special office space. At the same time, we set up a special team of mental health education, deputy secretary of the college, counselors have gotten the national two counselors qualification certificate, to provide students with professional mental counseling. Through the following characteristics of mental health education work and activities, on the one hand, to enhance the students' positive mental quality, on the other hand, to screen out the students who have mental problems and track guidance.

(1)Understanding the growth experience of students before they enter the school by autobiography. In order to solve the adaptability of freshmen's mental problems and establish archives for college students' mental health, institute requires all freshmen to write an autobiography, to understand students' growing experience and mental state with autobiography, to analyze the mental confusion and problems that may occur after entering school. Then we can solve the problem through targeted tutoring confusion and communication, to help freshmen adapt to college life.

(2) Holding on freshmen's mental drama contest. "Weaving the sun and mind, achieving the beautiful dream--The heart of the bay" workstation carries out a new mental drama contest for all freshmen in December each year, so that all new students involve in the game to improve students' interpersonal skills and comprehensive quality. The institute also hosted the first mental drama competition and the fourth mental drama contest successfully, and won the school mental drama competition awards for six consecutive years.

(3)Holding on lectures of mental health education more than twice a session. The lecture is divided into three levels, one is the professional knowledge of mental health training for student workers, two is students cadres and work methods for mental health liaison and peer counselors, three is college students mental health knowledge popularization for all students.

(4) Class group counseling activity. Workstation holds group counseling activity once a school year for all classes. In the cooperative activities, all members of the class produce benign interaction, through the mental interaction to explore the process of the self, to update the quality of positive psychology. We can find that group guidance have a direct role in promoting college students' interpersonal communication ability according to every activity feedback tables.

(5)The establishment of College Students' mental Health Association, make full use of the network to carry out the CSMHE. According to the mental characteristics of college students after "95", the author makes use of the language and form that they are easy to accept to develop CSMHE work. We has been built and operated by the network platform WeChat public numbers and Weaving the sun and mind, achieving the beautiful dream--The heart of the bay university students' Mental Health Association QQ group, the class members of the mental group qq. Release of mental health knowledge regularly, receive online booking and consultation, as well as the promotion of mental health education activities, etc.

(6) Carry out investigation and research work. "Weaving the sun and mind, achieving the beautiful dream--The heart of the bay" workstation members can make full use of their own professional advantage and actively carry out students' mental health professional textile engineering research work, to grasp the rules and characteristics of the students' development, and achieved a series of research results, a good foundation for students' mental health education in the future lay. 


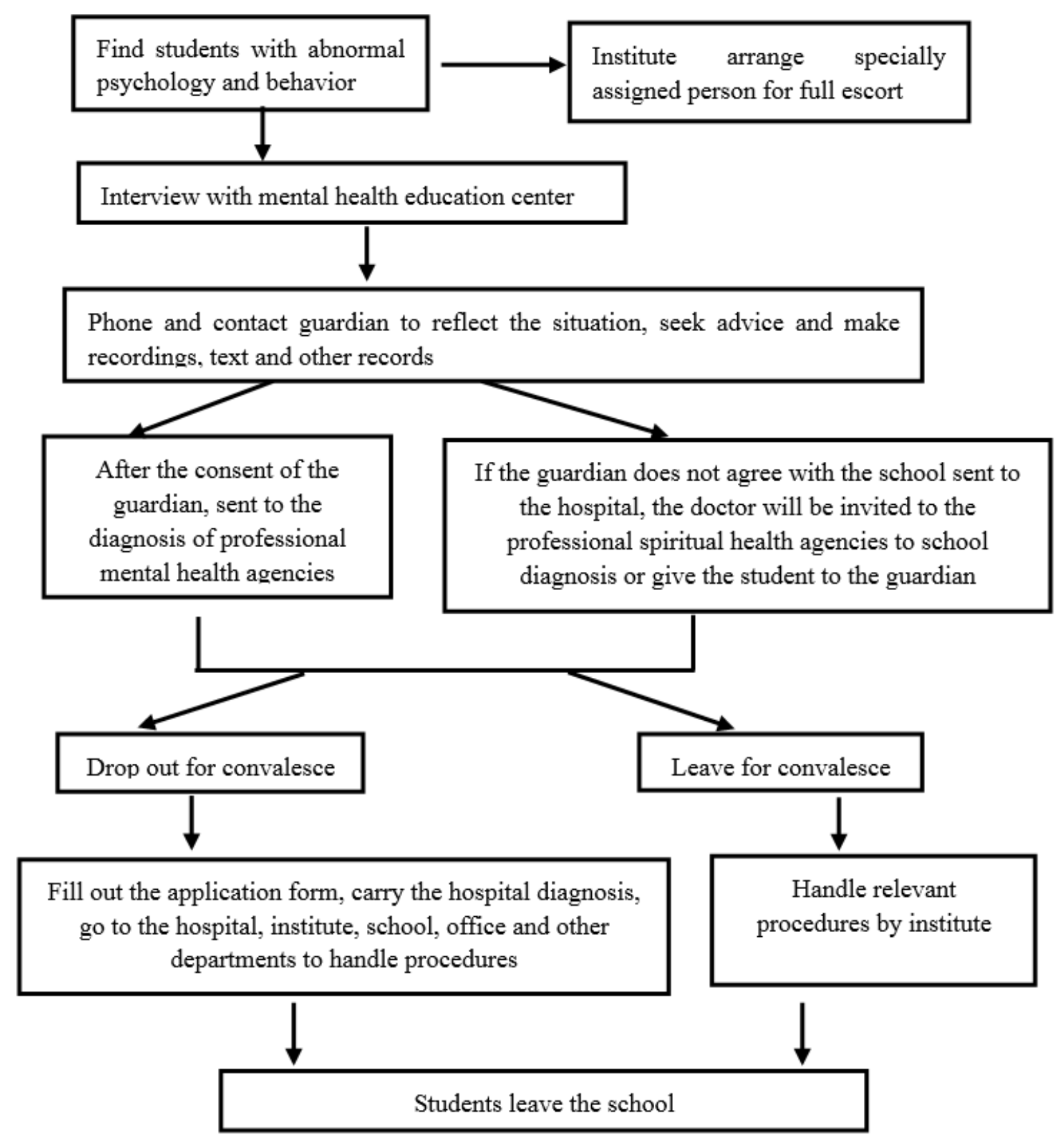

Fig.1 Mental crisis students leave, suspend school procedures flow chart

\section{Optimization of College Students Mental Crisis Intervention System, Do A Good Job of Investigation and Prevention}

The school has established the university student mental crisis intervention and the suicide prevention implementation plan, and has opened 24 hours mental crisis hot line, safeguards the student in the time which appears the mental question to have the prompt, the unimpeded channel to seek help. It is necessary to build a forewarning management to classify as blue, yellow and red depended on the order of severity of the mental health situation. The uninterruptedly tracking tutoring work is carried out to manage students who have signs of mental crisis.

\subsection{Screening for Students with Mental Crisis}

Our schools and institute select 5-10 mental commissioners with good mental health in the mental counseling team members as peer mental health every year and conduct related training. These students have a certain mental ability, to observe and find the potential mental crisis of students, timely report to the college by the usual learning activities, according to the severity of mental problems to determine the level of early warning of key students. 


\subsection{Mental Crisis Students' Tracking Guidance}

According to the warning level of the mental problems, we confirm different warning liable, and arrange dormitory, classroom liaison and peer counselors to concern about the mental state of students at any time. Counselors, deputy secretary and class instructor will talk with them on a regular basis, provide different categories of help and support for students with different mental problems owing to the reason of family conflicts, economic difficulties, interpersonal relationships, emotional problems.

\subsection{Strengthen the Work of the Time Node of Mental Crisis}

Safety and stable work topics conference and safety education will be convened regularly, the college confirms the theme and carry out the activities of safety warning, fire safety education and so on, Safety hazard investigation and prevention work during the school, before and after the holidays, graduated from school and other crisis prone period will be completed well.

\subsection{Intervention Treatment of Students with Mental Crisis}

The monthly track management process of key students who have mental crisis can be led into the student work system, college student work committee members can directly view the latest information on key students in the system. When students have mental crisis emergencies, college can deal with students with mental crisis according to the school mental crisis intervention and prevention Dutch act implementation plan, when the situation seriously affects the normal study life of students, the procedures of leave and suspension of schooling can be handled according to the process shown in the figure1.

The core of engineering education accreditation system is to take the student as the guidance. On the basis of cultivating and improving the comprehensive quality of college students, the professional attainment can reach a certain level. CSMHE plays a very important role in the comprehensive quality of students and the cultivation of students' professional quality. In such premise and background, we should gradually improve the CSMHE base facilities in the future, gradually expand the ranks of mental health education, and make the content of mental health education increasingly rich.

\section{Acknowledgements}

This paper is the result of humanities and social sciences research project "Research on the Mode Advances in Social Science, Education and Humanities Research of College Students' Education and Development under Perspective of Positive Psychological Capital" (Project Number: 1516B10) of Education Department of Hubei Province in 2015, and 2014 school fund project "A study on the positive mental quality education model of college students based on tutorial system".

\section{References}

[1]. .Chinese Engineering Education Quality Report (2013), Higher education evaluation center of Ministry of Education, 2014.

[2]. .Saxena, Shruti. Relationship between mental hardiness and mental health among college students. Indian Journal of Health \& Wellbeing. 2015, Vol. 6(8), p823-825.

[3]. .Yahong Li, Zhipeng Xu, Shunzhong Liu. Physical activity, self-esteem, and mental health in students from ethnic minorities attending colleges in China. Social Behavior \& Personality: an international journal. 2014, Vol. 42 (4), p529-537.

[4]. .Zhongguo Li, Shujun Li. College Students' psychological health education and psychological adjustment. Beijing Normal University Press, 2016. 